\title{
Introducing Anti-HBc Screening in Germany - Possible Implications for the Blood Donation Service
}

\author{
Thomas Zeiler $^{\mathrm{a}}$ Ralf Karger ${ }^{\mathrm{a}}$ Janus Slonka ${ }^{\mathrm{a}} \quad$ Klaus Radsak $^{\mathrm{b}} \quad$ Volker Kretschmer $^{\mathrm{a}}$ \\ a Institute for Transfusion Medicine and Haemostaseology, \\ b Institute for Virology, University Hospital, Philipps-University Marburg, Germany
}

\section{Key Words}

Anti-HBc · Transfusion-transmitted infections · Hepatitis B

\section{Summary}

Background: The German National Advisory Committee 'Blood' (Arbeitskreis Blut), recently recommended testing of blood and plasma donations for antibodies against the hepatitis B core antigen (anti-HBc). We assessed possible effects of this intended measure on donor deferral rate and look back procedures. Study Design and Methods: 3,964 consecutive blood donors were tested for anti-HBc for the first time. Anti-HBc-positive samples were further investigated employing an alternative anti-HBc test, quantitative determination of anti-HBs and HBV nucleic acid testing. Results: $46(1.16 \%)$ of the samples were tested specifically anti-HBc-positive. Following the recommendations of the Arbeitskreis Blut, 9 (0.23\% of all) donors had to be permanently deferred. Eight of these were repeat donors and had already donated 353 blood components which had been transfused to 285 recipients during the past 17 years. Conclusions: Implementation of anti-HBc testing in Germany will result in an acceptable loss of blood donors. However, the realization of look-back procedures is problematic due to the huge number of transfused blood components, the long period of time those donors gave blood, and particularly the impossibility to precisely determine the time of seroconversion. Therefore, when introducing anti-HBc testing, regulatory authorities should consider the described implications for look-back procedures.

\section{Schlüsselwörter \\ Anti-HBc · Infektionen durch Transfusion · Hepatitis B}

\section{Zusammenfassung}

Hintergrund: Der Arbeitskreis Blut am Bundesgesundheitsministerium hat unlängst in einem Votum (Votum 31 vom 17.3.2005) die Einführung einer generellen Anti-HBcTestung von Blut- und Plasmaspenden empfohlen. Wir untersuchten die möglichen Auswirkungen dieser geplanten Maßnahme auf Spenderausschlüsse und Rückverfolgungsverfahren. Studiendesign und Methoden: 3964 konsekutive Blutspender wurden erstmalig auf Anti-HBc getestet. Bei Anti-HBc-positiven Proben wurde ein alternativer Anti-HBc-Test, eine quantitative Bestimmung von Anti-HBs und ein hochempfindlicher Nukleinsäure-Test auf HBV-Genom durchgeführt. Ergebnisse: 46 (1,16\%) Proben waren spezifisch Anti-HBc-positiv. Entsprechend der Empfehlung des Arbeitskreises Blut mussten 9 Spender (0,23\% aller Spender) auf Dauer von der Spende ausgeschlossen werden. Davon waren 8 Dauerspender, die in einem Zeitraum von 17 Jahren insgesamt 353 Blutkomponenten gespendet hatten, welche 285 verschiedenen Empfängern transfundiert worden waren. Schlussfolgerungen: Die geplante Einführung der Anti-HBc-Testung dürfte zu einem vertretbaren Verlust an Blutspendern durch Spendeausschluss führen. Allerdings ergeben sich bei erstmalig positiv getesteten Dauerspendern Fragen bezüglich des Umfangs möglicher Rückverfolgungsverfahren aufgrund der großen Zahl der geleisteten Blutspenden, des langen Zeitraums der bisherigen Spendetätigkeit und der Unmöglichkeit, den Zeitpunkt einer Serokonversion retrospektiv festzulegen. Diese Fragen sollten bei einer behördlichen Anordnung der Anti-HBc-Testung berücksichtigt werden. Der Arbeitskreis Blut empfiehlt hier Rückverfolgungsverfahren nur bei nachgewiesener Serokonversion und/oder Nachweis von HBV-Genom beim Spender.

\begin{tabular}{ll}
\hline KARGER & @ 2006 S. Karger GmbH, Freiburg \\
Fax +497614520714 & Accessible online at: \\
$\begin{array}{l}\text { E-mail Information@Karger.de } \\
\text { www.karger.com }\end{array}$ & www.karger.com/tmh
\end{tabular}




\section{Introduction}

Since the early 1970s, in Germany, all blood and plasma donations have been tested for the presence of the hepatitis B surface antigen (HBsAg). However, HBV may be present in blood and blood components even when tested negative for HBsAg [1-6]. The estimated probability of HBV transmission by HBsAg-negative blood components in Germany at present is 1:230,000 which exceeds 20 times that of transfusion-transmitted HIV or HCV infections [7]. In order to further reduce the risk of transfusiontransmitted HBV infection, the National Advisory Committee 'Blood' (Arbeitskreis Blut) of the German Federal Ministry of Health recently recommended testing of blood donations for antibodies against the hepatitis B core antigen (anti-HBc) [8]. As a precautionary measure, cellular blood components and fresh frozen plasma reproducibly reactive are to be put in quarantine. The Arbeitskreis Blut stated: 'If an HBsAg-negative donor is anti-HBc-positive, the donation may be used and the donor may be approved for future donations if the serum or plasma has at least $100 \mathrm{IU} / \mathrm{l}$ antibodies against hepatitis B surface antigen (antiHBs) and no detectable HBV DNA (detection limit $30 \mathrm{IU} / \mathrm{ml}$ or 150 genome equivalents $/ \mathrm{ml}$ ). Repeated testing of the donor for anti-HBc, anti-HBs and HBV DNA status is not required for future donations.' Look-back procedures are requested by the recommendation of the 'Arbeitskreis Blut only if HBV DNA is detected or if a previously anti-HBc-negative donor becomes anti$\mathrm{HBc}$-positive (seroconversion).

There are reports of proven transmissions of hepatitis B by blood transfusion and organ transplantation from HBsAg- and anti-HBs-negative, anti-HBc-positive donors [9-13]. The PaulEhrlich-Institut (PEI) reported that 7 out of 18 cases of proven HBV transmission by blood components reported to the PEI could have been prevented by anti-HBc testing [8]. Considering these data, it seems prudent to exclude isolated anti-HBcpositive blood donors from further donation. However, it is not completely clear how the look-back procedure should be performed when a repeat donor who is tested for the first time is found to be positive for anti-HBc.
Fig. 1. Test algorithm for anti-HBc-positive, HBsAg-negative samples.

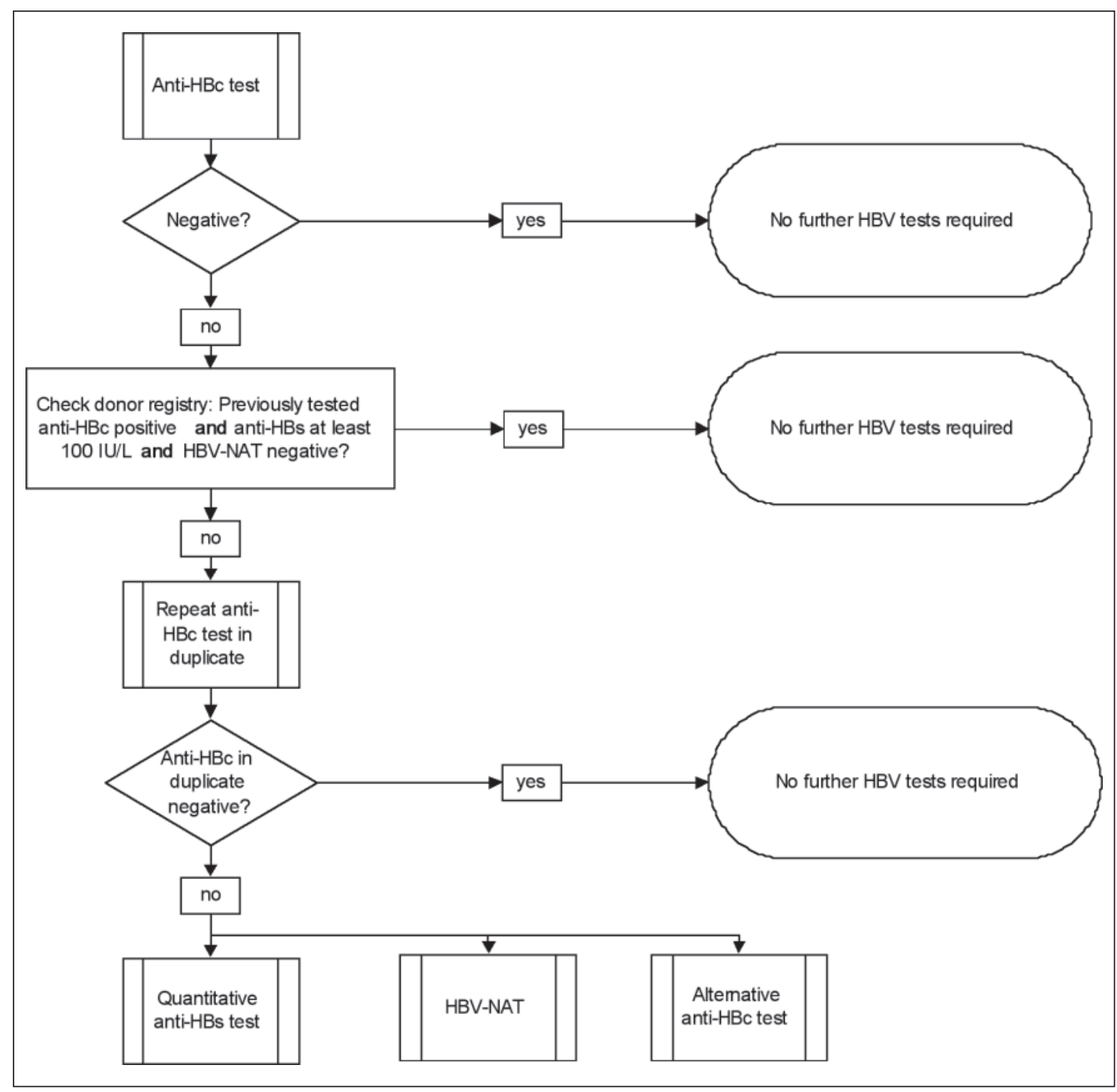

Transfus Med Hemother 2006;33:453-458 
We report on the various implications arising from the introduction of anti-HBc testing in a transfusion service predominantly drawing blood from repeat donors [14].

\section{Materials and Methods}

Following the recommendation of the Arbeitskreis Blut, we introduced anti-HBc testing in July 2005. A period of 3 months (July 4, 2005 to October 9,2005$)$ was evaluated. We examined 3,523 repeat donors and 441 donors willing to give blood for the first time without previous donations or testing. In our institute, the latter are examined and tested and then invited for blood donation after several weeks only if all test results fulfil the requirements. Therefore, the group of repeat donors also includes those who have undergone initial evaluation and come for their first do nation.

All anti-HBc positive samples were further investigated according to a fixed test algorithm (fig. 1), including an alternative anti-HBc test, quantitative determination of anti-HBs and $\mathrm{HBV}$ polymerase chain reaction (PCR) testing. Anti-HBc testing was considered to be specifically positive (or true positive), when the reactive sample was repeatedly positive in duplicate in the same test (confirmed) and the alternative anti-HBc test was also positive. All blood products previously donated by these donors were identified.

With respect to the well-known high frequency of non-specificity of anti$\mathrm{HBc}$ tests and the rather low infectivity of HBsAg-negative, anti-HBcpositive donors, we considered positive reactions in only one test method as unspecific, being well aware of the fact that the test methods might have different sensitivity.

\section{Hepatitis B Serology}

All donations from which platelet concentrates were derived $(n=1,129)$ were screened initially with an automated microparticle enzyme immunoassay for anti-HBc (AxSYM CORE ${ }^{\mathrm{TM}}$; Abbott, Wiesbaden, Germany) and HBsAg (AxSYM HBsAg; Abbott).

All other donations $(n=2,835)$ were tested with an automated enzymelinked immunosorbent assay (ELISA) for HBsAg (Ortho Antibody to HBsAg ELISA Test System 3; Ortho-Clinical Diagnostics, Neckargemünd, Germany) and anti-HBc (Ortho HBc ELISA Test System; Ortho-Clinical Diagnostics).

Confirmed anti-HBc-positive samples were tested for anti-HBs with a quantitative automated microparticle enzyme immunoassay (AxSYM AUSAB $^{\circledR}$; Abbott). Anti-HBs below $10 \mathrm{IU} / 1$ was considered as negative.

\section{Hepatitis B Nucleic Acid Testing}

Tests for HBV DNA were performed by a highly sensitive single sample PCR amplification technique with the Cobas ${ }^{\circledR}$ TaqMan Test (Roche Diagnostics $\mathrm{GmbH}$, Mannheim, Germany). The lower detection range of this assay is $6 \mathrm{IU} / \mathrm{ml}$ (95\% limit of detection), which is well below the detection limit of $30 \mathrm{IU} / \mathrm{ml}$ or 150 genome equivalents $/ \mathrm{ml}$ as requested by the recommendation of the Arbeitskreis Blut.

\section{Donor Records}

We determined the number of previous whole blood donations of all donors tested for anti-HBc, employing an automated query of our donor data base. For those repeat donors who tested specifically positive for anti-HBc and presented with anti-HBs titers $<100$ IU/1, we additionally determined the number of blood components manufactured from their previous whole blood donations and identified the number of transfused blood components. Since donor plasma samples for look-back procedures have to be stored for 1 year beyond the expiry date of a blood component, we also determined the number of blood donations with available donor archive samples.

\section{Statistics}

Donor records were processed with a computer system based on a central SQL server and peripheral microcomputer workstations (Swisslab II, FREY Computersysteme GmbH, Berlin, Germany). Calculations were performed, using MS Excel 2000 (Microsoft, Redmond, WA, USA), SPSS 12.0 for Windows (SPSS inc. Chicago, IL, USA), or SAS version 8.0 (SAS Institute, Cary, NC, USA). The t-test was used for comparison of the number of blood donations of anti-HBc confirmed positive and negative donors. The difference in specificity between both anti-HBc test systems was calculated with Fisher's exact test.

\section{Results}

\section{Serologic Findings}

Within 3 months, 3,964 donors were tested for anti-HBc for the first time. Of these, 441 applied for blood donation for the first time without previous donations or testing. 3,523 were repeat donors with previous donations or tests, including at least complete donor examination and serological tests. All 3,964 donors tested negative for HBsAg. 66 of the anti-HBc tests were initially positive $(1.67 \%$; $95 \%$ confidence interval $(95 \%$ CI) $1.27-2.05 \%$ ), and of these, 46 (1.16\%; 95\%-CI 0.83-1.4\%) were considered specifically positive (i.e. anti-HBc-positive in both tests). None was tested positive for HBV DNA. Samples from 20 donors $(0.5 \%)$ were considered false-positive. 14 of these were already negative when retested in duplicate using the same test system. The serologic findings of the anti-HBcpositive donors are displayed in table 1.

\section{Specifity of Anti-HBc Tests}

Donations that were anti-HBc-positive in both tests were considered true positives. Based on this assumption, the specificity of anti-HBc (Ortho) was $99.75 \%$, and that of anti-HBc (Abbott) $100 \%$. The calculated specificity of $100 \%$ may be lower, when evaluated with a greater sample. The difference in specificity was not statistically significant $(\mathrm{p}=0.186)$.

\section{Analysis of the Donor Population}

\section{Previous Blood Donations Of Anti-HBc-Positive and -Negative Donors}

The repeat donors at our institute $(\mathrm{n}=3,523)$ had given blood 16.4 (range 1-114) times on average. Those 46 donors with specifically positive anti-HBc tests performed slightly more blood donations $($ mean $=18.7$; range $1-97)$. However, this difference was not statistically significant $(\mathrm{p}=0.15)$.

\section{Donor Deferral, Previous Donations and Transfused Blood Components from Anti-HBc-Positive Donors}

Following the recommendations of the Arbeitskreis Blut, 14 $(0.35 \%$; $95 \%$-CI $0.17-0.53 \%)$ donors were temporarily or per- 
Table 1. Serologic findings in 3964 blood donors tested for Anti-HBc for the first time

\begin{tabular}{|c|c|c|c|c|c|c|c|}
\hline HBsAg & Anti-HBc (O) & Anti-HBc (A) & Anti-HBs, IU/1 & HBV PCR & Number & $\begin{array}{l}\% \text { of all first-time } \\
\text { blood donors }\end{array}$ & Donor status \\
\hline- & - & n.d. & n.d. & n.d. & 436 & 98.86 & admitted \\
\hline- & + & + & $\geq 100$ & neg.* & 4 & 0.91 & admitted \\
\hline- & + & + & $<100$ & neg.* & 1 & 0.23 & rejected \\
\hline \multicolumn{8}{|c|}{ Repeat donors $(n=3,523)$} \\
\hline- & - & n.d. & n.d. & n.d. & 2,343 & 66.51 & admitted \\
\hline- & n.d. & - & n.d. & n.d. & 1,119 & 31.76 & admitted \\
\hline- & $+/-$ & n.d. & n.d. & n.d. & 10 & 0.28 & admitted \\
\hline- & n.d. & $+/-$ & n.d. & n.d. & 4 & 0.11 & admitted \\
\hline- & + & + & $<10$ & neg.* & 4 & 0.11 & rejected \\
\hline- & + & + & $10-99$ & neg.* & 4 & 0.11 & rejected \\
\hline- & + & - & $<10$ & neg.* & 5 & 0.14 & temporary rejected \\
\hline- & + & - & $\geq 100$ & neg.* & 1 & 0.03 & temporary rejected \\
\hline
\end{tabular}

Anti-HBc $(\mathrm{O})=$ Ortho HBc ELISA Test System; Anti-HBc $(\mathrm{A})=$ AxSYM CORE; $-=$ negative; + = positive; n.d. = not determined; +/- = test initially positive, but negative when repeated in duplicate; neg.* = negative at a detection level of $6 \mathrm{IU} / \mathrm{ml}$ (95\% limit of detection).

Table 2. Detailed data of previous blood donations from 8 repeat donors with a positive anti-HBc test and anti-HBs $<100$ IU/l

\begin{tabular}{llccc}
\hline Anti HBs, IU/1 & Donors & Previous whole blood donations & Donor archive samples available* & Blood components \\
\hline$<10$ & 4 & $71(4-44)$ & $31 / 21$ & 171 \\
$10-99$ & 4 & $90(3-61)$ & $33 / 25$ & 137 \\
Total & 8 & $161(3-61)$ & $64 / 46$ & 353 \\
\hline
\end{tabular}

*If donor plasma samples for look-back procedures are stored for 3 years/2 years.

manently deferred from blood donation due to the test results, and the corresponding blood components were disposed. Five of these donors were temporarily deferred due to reproducibly positive anti- $\mathrm{HBc}$ results in only one of the two anti$\mathrm{HBc}$ tests and anti-HBs $<100$ IU/l. The residual 9 donors were permanently deferred because of a specifically positive anti-HBc test and anti-HBs $<100$ IU/l. Eight of these were repeat donors and had given a total of 161 (3-61) whole blood donations. Donor archive samples have to be stored for 1 year beyond expiry of the blood components and therefore usually are stored for only 2 years after donation because plasma normally expires after 1 year. We store donor archive samples for 3 years in our institute. Donor archive samples would have been available for only $28.8 \%$ of the donations concerned, given the usual storage time of 2 years. However, despite the extended storage of 3 years in our institute, this proportion could only be increased to $39.7 \%$. Detailed data of these donors are presented in table 2.

\section{Discussion}

In order to further reduce the risk of transfusion-transmitted hepatitis B infection in Germany, introduction of anti-HBc screening of blood and plasma donors has been recommended by the Arbeitskreis Blut in March 2005 [8]

It is beyond the scope of this paper to evaluate the value of anti-HBc and $\mathrm{HBV}$ nucleic acid testing for prevention of transfusion-transmitted HBV infection. This was done by previous studies [1,15-19] and resulted in the recommendation of the Arbeitskreis Blut. We analyzed the implications of the introduction of anti-HBc testing in a university blood service with respect to nonspecific test results, donor exclusion, and look-back procedures. Only blood specimens with positive anti-HBc screening tests were submitted to further investigation.

$66(1.67 \%)$ of all tested samples were initially reactive with anti-HBc; however, only $46(1.17 \%)$ were specifically posi- 
tives. Non-specifically positive tests represent a very undesirable effect in donor testing causing additional workload and may lead to temporal deferral of blood donors. Temporal deferral often results in a feeling of unease in the donors concerned. Many of these temporarily deferred donors finally discontinue donating blood. In our study, samples from 14 donors $(0.35 \%)$ initially were false-positive and were already negative when retested in duplicate using the same test system. Six $(0.15 \%)$ were reproducibly reactive in only one anti$\mathrm{HBc}$ test system. These 6 donors had to be temporarily deferred. Fortunately, this number of false-positive results is lower than expected from data previously reported by Hughes et al. [20] and certainly is due to improved and more specific test systems. In this respect, both tests showed a comparably high specificity which is supposed to be sufficient for the screening of a low-prevalence population.

The prevalence of specifically positive anti-HBc was $1.13 \%$ in the donors applying to be tested for blood donation for the first time without previous donations or testing and $1.17 \%$ in repeat donors (after exclusion of false-positive tests) and thus in the range expected in a low-prevalence area as previously determined in a German donor population [1]. It is interesting that, like in a previous study by Christensen et al. [21], there was no difference in the prevalence of specifically anti-HBc-positive donors between first-time donors and repeat donors when tested for anti-HBc for the first time. Obviously, isolated anti-HBcpositive repeat donors do not undergo a negative selection process due to occasional conspicuous test results or uncovering of other exclusion criteria during donor history taking.

By applying the recommendations of the Arbeitskreis Blut, we had to permanently exclude $9(0.23 \%)$ donors, 8 of whom were repeat donors, from further blood donations. If we had followed a more conservative approach, which is in use in other countries (e.g. USA, Japan), and had excluded all donors with a specifically positive anti-HBc test, 46 (1.16\%; 95\%-CI $0.83-1.49 \%$ ) donors would have had to be permanently deferred from further donation. This difference is quite relevant since increasing the deferral rate from 0.23 to $1.17 \%$ (or even higher) would result in a projected additional loss of at least 30,000 blood donations per year in Germany. The recommendation of the Arbeitskreis Blut takes account of this by restricting donor exclusion to those anti-HBc-positive donors who have anti-HBs titers $<100 \mathrm{IU} / 1$ and/or detectable HBV DNA. We believe that this loss of donors is acceptable with respect to a possible reduction of transfusion-transmitted hepatitis B infections. However, these 8 repeat blood donors had donated 353 blood components which had been transfused to 285 recipients within the last 17 years. None of these donors was ever involved in a recipient-driven look-back investigation. From that point of view, it is a sad but inevitable duty to defer those faithful donors. Furthermore, it is difficult for these donors to understand why they are excluded from donation while at the same time they are told that they are most likely not infectious. This discrepancy causes uncertainty. The exclusion from donation may be perceived as a stigma that may even influence the conduct of one's life.

With respect to look-back procedures, there still remain unresolved issues. Usually, donor-driven look-back procedures are initiated in case of seroconversion, i.e. the donor was tested negative on previous occasions and now is tested specifically positive due to infection. The time period for which a lookback procedure has to be performed can be defined quite well in these cases. However, since there are no previous anti-HBc test results when a repeat donor is tested for the first time, this period cannot be defined. In our study, which was conducted in 2005, the earliest blood donation of an involved repeat donor dated back to 1988. Plasma samples which are to be taken from every blood donation and kept for retrospective investigations could help to limit the look-back intervals. However, in Germany, these plasma samples have to be stored only for 1 year beyond the expiry of the blood components (usually resulting in storage of 2 years after donation) and were available for retesting only in a minority of the donations concerned. Despite an extended storage of 3 years after donation at our institute, plasma samples were still available for only $40 \%$ of the involved blood donations. Thus, even these plasma samples may be of rather little value for limiting the appropriate time period for tracing back earlier donations. The magnitude of the problem may be illustrated by the following considerations. In our study there was a repeat donor, tested positive for anti-HBc, who had given blood 61 times in the past 17 years. A look-back procedure to the first donation for this donor would include more than 100 recipients and result in immense workload and costs for the transfusion service and the clinicians. Due to the prevalence of hepatitis B in the general population and particularly in formerly hospitalized patients, it is inevitable that there will be recipients with markers for hepatitis B. However, the causality of positive hepatitis $\mathrm{B}$ markers in recipients and the anti-HBc-positive blood donor may hardly be established, as was already described by Allain et al. [22] who reported markers of HBV infection in 12 of 278 recipients of blood from 171 anti-HBc-positive blood donors. However, the authors considered an association with transfusion was likely only in two and possibly in four of these recipients. It is noteworthy that none of the involved donors investigated by Allain et al. [22] had detectable HBV DNA, even 6-40 months after donation. Thus, DNA typing mostly may not help to establish causality, even in suspected cases.

It is obvious that look-back procedures, once started, will represent a heavy burden, not only with respect to workload and costs but also with respect to uncertainty of recipients. Finally, these look-back procedures will lead to legal embroilment if the causality of presumed transfusion-transmitted HBV infections remains unsolved. The latter is to be expected in most cases of look-back investigations on anti-HBc-positive donors [23-25]. Thus, the recommendations of the Arbeitskreis Blut are reasonable, restricting look-back procedures to those donors who are tested positive for HBV DNA by single sample nucleic 
acid testing and to proven seroconversions. This recommendation will restrict look-back procedures to a few cases. In our study, none of the 46 donors with a reproducibly reactive anti$\mathrm{HBc}$ test was tested positive for HBV DNA. Thus, no lookback procedures had to be performed. This may be due to our highly selected donors as previously described by [14].

In conclusion, the introduction of anti-HBc in order to further reduce the risk of transfusion-transmitted HBV infec- tion will not be complicated by unspecificity of the anti$\mathrm{HBc}$ tests. The loss of donors by applying the recommendation of the Arbeitskreis Blut is acceptable. The restriction of look-back procedures to donors with detectable HBV DNA and proven seroconversion is reasonable. However, when introducing anti-HBc testing, regulatory authorities have to consider described implications for look-back procedures.

\section{References}

1 Hennig H, Puchta I, Luhm J, Schlenke P, Goerg S, Kirchner H: Frequency and load of hepatitis B virus DNA in first-time blood donors with antibodies to hepatitis B core antigen. Blood 2002;100: 2637-2641.

2 Brechot C, Degos F, Lugassy C, Thiers V, Zafrani S, Franco D, Bismuth H, Trepo C, Benhamou JP, Wands J: Hepatitis B virus DNA in patients with chronic liver disease and negative tests for hepatitis B surface antigen. N Engl J Med 1985;312:270-276.

3 Gomes SA, Yoshida CF, Niel C: Detection of hepatitis B virus DNA in hepatitis B surface antigennegative serum by polymerase chain reaction: evaluation of different primer pairs and conditions. Acta Virol 1996;40:133-138.

4 Hennig H, Dennin RH, Haase D, Kirchner H $\mathrm{HBV}-\mathrm{DNA}$ positive findings in $\mathrm{HBsAg}$ negative blood donors and patients; in Müller N, Sibrowski W, Stangel W (Hrsg): Transfusionsmedizin 1996/97. Beitr Infusionsther Transfusionsmed. Basel, Karger, 1997, vol 34, pp 26-30.

${ }_{5}$ Yotsuyanagi H, Yasuda K, Iino S, Moriya K, Shintani Y, Fujie H, Tsutsumi T, Kimura S, Koike K: Persistent viremia after recovery from self-limited acute hepatitis B. Hepatology 1998;27:1377-1382.

$\checkmark 6$ Blum HE, Offensperger WB, Walter E, Offensperger S, Gerok W: Latent hepatitis B virus infection with full-length viral genome in a patient serologically immune to hepatitis B virus infection. Liver 1988;8:307-316.

7 Offergeld R, Faensen D, Ritter S, Hamouda O: Human immunodeficiency virus, hepatitis $\mathrm{C}$ and hepatitis B infections among blood donors in Germany 2000-2002: risk of virus transmission and the impact of nucleic acid amplification testing. Euro Surveill 2005;10:8-11.

$>$ Arbeitskreis Blut: Announcement of the National Advisory Committee 'Blood' (Arbeitskreis Blut) of the German Federal Ministry of Health and Social Security (Votum V 31). Bundesgesundheitsbl Gesundheitsforsch Gesundheitsschutz 2005:48:698699.
9 Larsen J, Hetland G, Skaug K: Posttransfusion hepatitis B transmitted by blood from a hepatitis B surface antigen-negative hepatitis B virus carrier. Transfusion 1990;30:431-432.

10 Norder H, Hammas B, Larsen J, Skaug K, Magnius LO: Detection of HBV DNA by PCR in serum from an HBsAg negative blood donor implicated in cases of post-transfusion hepatitis B. Arch Virol Suppl 1992;4:116-118.

11 Hoofnagle JH, Seeff LB, Bales ZB, Zimmerman HJ: Type B hepatitis after transfusion with blood containing antibody to hepatitis B core antigen. $\mathrm{N}$ Engl J Med 1978;298:1379-1383.

12 Dickson RC, Everhart JE, Lake JR, Wei Y, Seaberg EC, Wiesner RH, Zetterman RK, Pruett TL, Ishitani MB, Hoofnagle JH: Transmission of hepatitis B by transplantation of livers from donors positive for antibody to hepatitis B core antigen. The National Institute of Diabetes and Digestive and Kidney Diseases Liver Transplantation Database. Gastroenterology 1997;113:1668-1674

13 Douglas DD, Rakela J, Wright TL, Krom RA, Wiesner RH: The clinical course of transplantationassociated de novo hepatitis B infection in the liver transplant recipient. Liver Transpl Surg 1997;3: 105-111.

14 Kretschmer V, Weippert-Kretschmer M, Slonka J, Karger R, Zeiler T: Perspectives of paid whole and plasma donation. Dev Biol (Basel) 2005;120:101111.

15 Kleinman SH, Strong DM, Tegtmeier GG, Holland PV, Gorlin JB, Cousins C, Chiacchierini RP, Pietrelli LA: Hepatitis B virus (HBV) DNA screening of blood donations in minipools with the COBAS AmpliScreen HBV test. Transfusion 2005;45:12471257.

16 Ramia S, Ramlawi F, Kanaan M, Klayme S, Naman R: Frequency and significance of antibodies against hepatitis B core (anti-HBc) antigen as the only serological marker for hepatitis B infection in Lebanese blood donors. Epidemiol Infect 2005;133: 695-699.
17 Silva CM, Costi C, Costa C, Michelon C, Oravec R, Ramos AB, Niel C, Rossetti ML: Low rate of occult hepatitis $\mathrm{B}$ virus infection among anti-HBc positive blood donors living in a low prevalence region in Brazil. J Infect 2005;51:24-29.

18 Arraes LC, Ximenes R, Andrieu JM, Lu W, Barreto S, Pereira LM, Castelo A: The biological meaning of anti-HBC positive result in blood donors: relation to HBV-DNA and to other serological markers. Rev Inst Med Trop Sao Paulo 2003;45:137-140.

19 Roth WK, Weber M, Petersen D, Drosten C, Buhr S, Sireis W, Weichert W, Hedges D, Seifried E: NAT for HBV and anti-HBc testing increase blood safety. Transfusion 2002;42:869-875.

20 Hughes W, Barr A, Dow BC, Follett EA, Barbara, JA: A multicentre assessment of the specificity of ten anti-HBc screening tests. Transfus Med 1995;5 225-230.

21 Christensen PB, Titlestad IL, Homburg KM, Georgsen J, Kristensen T: Hepatitis B core antibodies in Danish blood donors: a surrogate marker of risk behaviour. Vox Sang 2001;81:222-227.

22 Allain JP, Hewitt PE, Tedder RS, Williamson LM: Evidence that anti-HBc but not HBV DNA testing may prevent some HBV transmission by transfusion. Br J Haematol 1999;107:186-195.

23 Zervou E K, Dalekos GN, Boumba DS, Tsianos EV: Value of anti-HBc screening of blood donors for prevention of $\mathrm{HBV}$ infection: results of a 3-year prospective study in Northwestern Greece. Transfusion 2001;41:652-658.

24 Tseliou P, Spiliotakara A, Dimitracopoulos GO, Christofidou M: Detection of hepatitis B virus DNA in blood units with anti-HBc as the only positive serological marker. Haematologia (Budap) 2000;30:159-165.

25 Howell DR, Webster MH, Barbara JA: Retrospective follow-up of recipients and donors of blood donations reactive for anti-HBc or for single $\mathrm{HCV}$ antibodies. Transfus Med 2000;10:265-269. 